\title{
The haemagglutination inhibition and the Hogben test in pregnancy
}

\author{
J. SHEA AND A. J. N. WARRACK \\ From the Pregnancy Diagnosis Unit, City General Hospital, Sheffield
}

SYNOPSIS Haemagglutination inhibition tests are easy to perform and easy to read. The results are reproducible and are not subject to the vagaries of supply and temperament inherent in tests using living creatures. In a series of tests with Prepuerin done in parallel with the Hogben test the former has shown a higher sensitivity. There have been three false positive results with Prepuerin tests in the series but it was not established on general grounds that pregnancy was not in fact present.

The Pregnancy Diagnostic Unit at Sheffield covers the Midlands, the north of England, and Wales, and 20,000 tests a year are performed by the Xenopus method. Patients are referred with threatened abortion, hydatidiform mole, abnormal implantations, tuberculosis, heart disease, mental disturbances, and such social problems as pregnancy in the unmarried mother. The Centre does not in theory cover normal pregnancies.

It requires a large colony of Xenopus laevis to maintain an output of even 50 tests a day. As many as 4,000 toads are necessary if they are to have adequate rest and good husbandry. Any marked increase in the demand for Hogben tests can mean negative results.

Xenopus laevis can be bred in captivity (Larkin, 1955) but this can be troublesome and uneconomic where large numbers are involved (Schwabacher and Elkan, 1953). Toads for the Sheffield Unit are imported from South Africa and we are dependent on the suppliers both for adequate numbers and for satisfactory specimens. In 1954 the Unit had severely to restrict its output as a result of difficulties in obtaining toads ('Peterborough', 1954) and in 1958 tests had to be suspended owing to an epidemic of Streptococcus pyogenes A which almost destroyed the entire toad colony. Considerable benefit, therefore, would ensue from a procedure less dependent on a creature as temperamental in its outlook as it is difficult to obtain in regular quantities.

The haemagglutination inhibition test for pregnancy is based on the tanned red cell technique described by Boyden (1951) as modified by Wide and Gemzell (1960) for a gonadotrophin-antigonadoReceived for publication 22 May 1963 trophin system. Fulthorpe (1962) has further modified the technique to utilize formalized tanned red cells in a one-stage test.

Human chorionic gonadotrophin-sensitized sheep red cells are agglutinated by rabbit anti-human chorionic gonadotrophin. If a system based on this phenomenon is exposed to a solution of human chorionic gonadotrophin, i.e., pregnancy urine, the reaction is inhibited and disagglutination occurs. Several tests based on this reaction are now on the market and the object of this communication is to report our experience with one of them.

The reagent selected for the present series is prepared by Burroughs Wellcome \& Co. and called Prepuerin.

The system consists of two suspensions: (1) a test suspension of formalin-preserved sheep red cells sensitized with human chorionic gonadotrophin and already agglutinated by rabbit anti-human chorionic gonadotrophin which gives a typical agglutination pattern characterized by an even distribution of cells when the suspension is reconstituted in a suitable buffer; (2) a control suspension of formalinpreserved sheep red cells stabilized in normal rabbit serum and not sensitized with human chorionic gonadotrophin. When the test suspension is exposed to a solution of human chorionic gonadotrophin or pregnancy urine disagglutination occurs and a negative pattern, characterized by a ring of cells with a clear centre, develops. This pattern is clear cut and quite different from the agglutination pattern. It indicates the presence of human chorionic gonadotrophin. The test is put up in dilutions of 1 in 5,1 in 10 , and 1 in 20 , using a borate buffer solution, and is read on the following day. In 
practice we have found that the result can often be read in a few hours and that with few exceptions tests when positive show disagglutination to a titre of 1 in 20.

In the past few months, as and when supplies of Prepuerin have become available, we have selected at random 30 samples of urine a week received at the Centre and performed the test in parallel with the Hogben test. In all these cases a follow-up letter was sent to the doctor concerned asking for the final diagnosis. There is naturally a time lag of two or three months before a reply is received, but so far 311 out of 729 tests have been followed up. Table I gives the comparative figures for 311 tests in cases of suspected pregnancy followed up and divided into gestation periods of four weeks up to 40 weeks. In order to obtain a series extending over the whole gestation period we obtained specimens from patients in the last few weeks of pregnancy attending the ante-natal clinics at this hospital. (Fifty-nine cases of hydatidiform mole, suspected chorionic epithelioma, and malignant testicular tumour are excluded from this series.) It will be seen that although the follow-up shows 45 false negative Hogben tests there have been only three false negative results in Prepuerin tests in which pregnancy has definitely been diagnosed.
Two occurred between 16 and 24 weeks when the output of hormone is often low. The Hogben tests: were also negative in these cases. The other false? negative reaction was in a case tested within 10 days of the missed period. The Hogben test was positive in this case. The output of hormone rarely reaches a titre high enough to give a reaction withine 10 days. There also appears to have been a falsên positive Hogben and Prepuerin result in a patien 5 thought to have been 14 weeks pregnant. The follow-up report on this case, however, was indefinited because it was merely stated: 'Laparotomy did not confirm an ovarian cyst and there was appendicitis.? There were two apparently false positive results iṇ Prepuerin tests in cases in which the social circum? stances were such as to throw some doubt on theo validity of the final diagnosis of 'not pregnant' In one of these cases, thin-layer partition chromato? graphy gave a positive result for pregnandiol $\vec{Z}$ indicating pregnancy.

In the course of the follow-up 17 replies wer@ received indicating the final diagnosis as abortion of miscarriage. These results are given in Table II. In this series three cases showed a positive Hogben testo and five a positive Prepuerin test. These results were not unexpected as it is recognized that where the pregnancy is of poor quality and there is the

TABLE I

RESULTS WITH HOGBEN AND PREPUERIN TESTS IN 311 CASES OF SUSPECTED PREGNANCY

\begin{tabular}{|c|c|c|c|c|c|c|c|c|}
\hline \multirow{2}{*}{$\begin{array}{l}\text { Period of } \\
\text { Time } \\
\text { (wk.) }\end{array}$} & \multirow{2}{*}{$\begin{array}{l}\text { Number } \\
\text { of } \\
\text { Cases }\end{array}$} & \multicolumn{2}{|c|}{ Hogben Results } & \multicolumn{2}{|c|}{ Prepuerin Results } & \multicolumn{2}{|c|}{ Final Diagnosis } & \multirow{2}{*}{$\begin{array}{l}\text { Excess of } \\
\text { Positive } \\
\text { Prepuerin } \\
\text { over } \\
\text { Positive } \\
\text { Hogben } \\
\text { Results }\end{array}$} \\
\hline & & Positive & $\begin{array}{l}\text { Nega- } \\
\text { tive }\end{array}$ & Positive & $\begin{array}{l}\text { Nega- } \\
\text { tive }\end{array}$ & Pregnant & $\begin{array}{l}\text { Not } \\
\text { Pregnant }\end{array}$ & \\
\hline
\end{tabular}

\section{Accuracy}

$\frac{\text { Hogben Results }}{\text { True } \frac{\text { False }}{\text { Nega- Positive }}} \frac{\text { Prepuerin Results }}{\text { True } \frac{\text { False }}{\text { Nega- Positive }}}$
tive

tive

\begin{tabular}{llllllll}
\hline Not stated & 25 & 12 & 13 & 14 & 11 & 14 & 11 \\
$0-4$ & 63 & 30 & 33 & 42 & 21 & 42 & 21
\end{tabular}

112

2
12

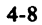

8-12

12-16

Totals

$\begin{array}{lll}73 & 38 & 35\end{array}$

46
41
29

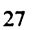

7

$\begin{array}{ll}48 & 34 \\ 43 & 23\end{array}$

14
20

29

27
11
6
6

311

$\begin{array}{rr}13 & 14 \\ 3 & 8 \\ 4 & 2 \\ 2 & 4 \\ 4 & 1 \\ 4 & 0 \\ 167 & 144\end{array}$

16
6
5
4
5
4
212

11
5
1
2
0
0
99

17
7
5
4
5
4
212

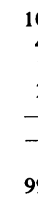

10
4
1
2
-
-
99

3
3
1
2
1
0
45

23
51

2
12

-

- 25


possibility of abortion, the output of hormone may be low (Hobson, 1953-54).

Table III gives the comparative figures for the 729 tests done in the series. Follow-up reports are still awaited for 342 of the cases but in view of our past experience that any suspicion of a false-positive result is invariably reported to us long before our follow-up letter arrives, we feel that it is unlikely that any significant number of the 98 positive results in Prepuerin tests over Hogben results will prove to be false. We have already indicated in our comments on the so-called false-positive cases followed up to date that our experience over many years with the Hogben tests has shown us that there is nearly always some social or matrimonial explanation for an anomalous result.

In the course of the investigation 59 specimens of urine from cases of suspected hydatidiform mole, chorionic epithelioma, or testicular tumour were received. Table IV indicates that there is close correlation between the tests. The Prepuerin test in fact proved positive in one case of testicular malignancy and two out of 31 proved cases of hydatidiform mole showed the presence of human chorionic gonadotrophin by both Prepuerin and Hogben tests. In four patients with suspected hydatidiform mole who later proved to be pregnant, both the Hogben and Prepuerin tests were positive. Of two cases of chorionic epithelioma one gave a positive result on both Hogben and Prepuerin tests and the other was positive in the Hogben test only but not in dilution.

\section{OTHER HAEMAGGLUTINATION INHIBITION TESTS}

We have little experience of other haemagglutination inhibition reagents on the market but these seem equally satisfactory. Pregnosticon (Organon) is essentially similar to Prepuerin but appears to have the advantage of the results being readable in a shorter period. We have only done 20 tests with this material and have found exact correlation with the Prepuerin test. Denco (Denver Laboratories) has also recently become available. We have only done 10 tests with Denco but have again found exact

TABLE II

RESULTS IN ABORTIONS AND MISCARRIAGES

\begin{tabular}{|c|c|c|c|c|c|c|c|c|c|c|c|c|c|}
\hline \multirow{4}{*}{$\begin{array}{l}\text { Period } \\
\text { of Time } \\
\text { (wk.) }\end{array}$} & \multirow{4}{*}{$\begin{array}{l}\text { Number } \\
\text { of } \\
\text { Cases }\end{array}$} & \multicolumn{2}{|c|}{ Hogben Test } & \multicolumn{2}{|c|}{ Prepuerin Test } & \multirow{4}{*}{$\begin{array}{l}\text { Final } \\
\text { Diagnosis }\end{array}$} & \multirow{4}{*}{$\begin{array}{l}\text { Excess } \\
\text { Positive } \\
\text { Prepuerin } \\
\text { over Hogben } \\
\text { Tests }\end{array}$} & \multicolumn{6}{|c|}{ Accuracy } \\
\hline & & \multirow[t]{3}{*}{ Positive } & \multirow[t]{3}{*}{ Negative } & \multirow[t]{3}{*}{ Positive } & \multirow[t]{3}{*}{ Negative } & & & \multicolumn{3}{|c|}{ Hogben Test } & \multicolumn{3}{|c|}{ Prepuerin Test } \\
\hline & & & & & & & & True & False & & True & False & \\
\hline & & & & & & & & & Negative & Positive & & Negative & Positive \\
\hline
\end{tabular}

\begin{tabular}{|c|c|c|c|c|c|c|c|c|c|c|c|c|c|}
\hline $\begin{array}{c}4-5 \\
8-12 \\
12-16 \\
16-24\end{array}$ & $\begin{array}{l}1 \\
7 \\
5 \\
4\end{array}$ & $\begin{array}{l}0 \\
1 \\
2 \\
0\end{array}$ & $\begin{array}{l}1 \\
6 \\
3 \\
4\end{array}$ & $\begin{array}{l}1 \\
1 \\
2 \\
1\end{array}$ & $\begin{array}{l}0 \\
6 \\
3 \\
3\end{array}$ & $\begin{array}{l}\text { Abortion } \\
\text { Abortion } \\
\text { Abortion } \\
\text { Abortion }\end{array}$ & $\begin{array}{l}1 \\
0 \\
0 \\
1\end{array}$ & $\begin{array}{l}0 \\
1 \\
2 \\
0\end{array}$ & $\begin{array}{l}1 \\
6 \\
3 \\
4\end{array}$ & $\begin{array}{c}- \\
-\end{array}$ & $\begin{array}{l}1 \\
1 \\
2 \\
1\end{array}$ & $\begin{array}{l}- \\
6 \\
3 \\
3\end{array}$ & - \\
\hline Totals & 17 & 3 & 14 & 5 & 12 & & 2 & 3 & 14 & - & 5 & 12 & - \\
\hline
\end{tabular}

TABLE III

COMPARATIVE RESULTS FOR HOGBEN AND PREPUERIN TESTS IN 729 CASES

\begin{tabular}{|c|c|c|c|c|c|c|}
\hline \multirow{2}{*}{$\begin{array}{l}\text { Time since Last Menstrual } \\
\text { Period }\end{array}$} & \multirow{2}{*}{$\begin{array}{l}\text { Number of } \\
\text { Cases }\end{array}$} & \multicolumn{2}{|c|}{ Hogben Tests } & \multicolumn{2}{|c|}{ Prepuerin Tests } & \multirow{2}{*}{$\begin{array}{l}\text { Excess Positive } \\
\text { Prepuerin over Positive } \\
\text { Hogben Tests }\end{array}$} \\
\hline & & Positive & Negative & Positive & Negative & \\
\hline $\begin{array}{l}\text { Not stated } \\
0-4 \text { weeks } \\
4-8 \text { weeks } \\
\text { 8-12 weeks } \\
12-16 \text { weeks } \\
16-20 \text { weeks } \\
20-24 \text { weeks } \\
24-28 \text { weeks } \\
28-32 \text { weeks } \\
32-36 \text { weeks } \\
36-40 \text { weeks }\end{array}$ & $\begin{array}{r}20 \\
152 \\
154 \\
114 \\
86 \\
55 \\
31 \\
15 \\
13 \\
8 \\
5\end{array}$ & $\begin{array}{r}7 \\
75 \\
86 \\
60 \\
44 \\
28 \\
13 \\
5 \\
3 \\
5 \\
4\end{array}$ & $\begin{array}{r}13 \\
77 \\
68 \\
54 \\
42 \\
27 \\
18 \\
10 \\
10 \\
3 \\
1\end{array}$ & $\begin{array}{r}10 \\
103 \\
104 \\
76 \\
57 \\
36 \\
21 \\
5 \\
6 \\
6 \\
4\end{array}$ & $\begin{array}{r}10 \\
49 \\
50 \\
38 \\
29 \\
19 \\
10 \\
10 \\
7 \\
2 \\
1\end{array}$ & $\begin{array}{r}3 \\
28 \\
18 \\
16 \\
13 \\
8 \\
8 \\
0 \\
3 \\
1 \\
0\end{array}$ \\
\hline Total & 653 & 330 & 323 & 428 & 225 & 98 \\
\hline $\begin{array}{l}\text { Moles etc. (Table IV) } \\
\text { Abortions, etc. (Table II) }\end{array}$ & $\begin{array}{l}59 \\
17\end{array}$ & $\begin{array}{l}8 \\
3\end{array}$ & $\begin{array}{l}51 \\
14\end{array}$ & $\begin{array}{l}8 \\
5\end{array}$ & $\begin{array}{l}51 \\
12\end{array}$ & $\overline{2}$ \\
\hline Total no. of cases tested & 729 & 341 & 388 & 441 & 288 & 100 \\
\hline
\end{tabular}


TABLE IV

59 CASES OF SUSPECTED HYDATIDIFORM MOLE, CHORION EPITHELIOMA, OR TESTICULAR TUMOUR

Preliminary Diagnosis Number of Cases

\begin{tabular}{|c|c|c|c|c|c|c|}
\hline \multirow[t]{2}{*}{ Preliminary Diagnosis } & \multirow{2}{*}{$\begin{array}{l}\text { Number } \\
\text { of Cases }\end{array}$} & \multicolumn{2}{|c|}{ Hogben Test } & \multicolumn{2}{|c|}{ Prepuerin Test } & \multirow[t]{2}{*}{ Follow-up } \\
\hline & & Positive & Negative & Positive & Negative & \\
\hline Mole & 29 & - & 29 & - & 29 & Confirmed \\
\hline Mole & 16 & - & 16 & - & 16 & Not confirmed \\
\hline Mole & 4 & 4 & 一 & 4 & - & Pregnant \\
\hline Mole & 2 & 2 & - & 2 & - & Confirmed \\
\hline Chorion epithelioma & 1 & 1 & - & 1 & - & Confirmed \\
\hline Chorion epithelioma & 1 & 1 & - & - & 1 & Confirmed \\
\hline Malignant tumours of testicle & 1 & - & 1 & - & 1 & $\begin{array}{l}\text { Confirmed chorion epithelioma, no } \\
\text { spread yet }\end{array}$ \\
\hline Malignant tumours of testicle & 1 & - & 1 & 1 & - & $\begin{array}{l}\text { Confirmed chorion epithelioma, died } \\
\text { multiple metastases }\end{array}$ \\
\hline Malignant tumours of testicle & 4 & - & 4 & - & 4 & Chorion epithelioma not confirmed \\
\hline Total & 59 & 8 & 51 & 8 & 51 & \\
\hline
\end{tabular}

\begin{tabular}{|c|c|c|c|c|c|c|}
\hline \multirow[t]{2}{*}{ Preliminary Diagnosis } & \multirow{2}{*}{$\begin{array}{l}\text { Number } \\
\text { of Cases }\end{array}$} & \multicolumn{2}{|c|}{ Hogben Test } & \multicolumn{2}{|c|}{ Prepuerin Test } & \multirow[t]{2}{*}{ Follow-up } \\
\hline & & Positive & Negative & Positive & Negative & \\
\hline Mole & 29 & - & 29 & - & 29 & Confirmed \\
\hline Mole & 16 & - & 16 & - & 16 & Not confirmed \\
\hline Mole & 4 & 4 & - & 4 & - & Pregnant \\
\hline Mole & 2 & 2 & - & 2 & - & Confirmed \\
\hline Chorion epithelioma & 1 & 1 & - & 1 & - & Confirmed \\
\hline Chorion epithelioma & 1 & 1 & - & - & 1 & Confirmed \\
\hline Malignant tumours of testicle & 1 & - & 1 & - & 1 & $\begin{array}{l}\text { Confirmed chorion epithelioma, no } \\
\text { spread yet }\end{array}$ \\
\hline Malignant tumours of testicle & 1 & - & 1 & 1 & - & $\begin{array}{l}\text { Confirmed chorion epithelioma, died } \\
\text { multiple metastases }\end{array}$ \\
\hline Malignant tumours of testicle & 4 & - & 4 & - & 4 & Chorion epithelioma not confirmed \\
\hline Total & 59 & 8 & 51 & 8 & 51 & \\
\hline
\end{tabular}

\begin{tabular}{|c|c|c|c|c|c|c|}
\hline \multirow[t]{2}{*}{ Preliminary Diagnosis } & \multirow{2}{*}{$\begin{array}{l}\text { Number } \\
\text { of Cases }\end{array}$} & \multicolumn{2}{|c|}{ Hogben Test } & \multicolumn{2}{|c|}{ Prepuerin Test } & \multirow[t]{2}{*}{ Follow-up } \\
\hline & & Positive & Negative & Positive & Negative & \\
\hline Mole & 29 & - & 29 & - & 29 & Confirmed \\
\hline Mole & 16 & - & 16 & - & 16 & Not confirmed \\
\hline Mole & 4 & 4 & - & 4 & - & Pregnant \\
\hline Mole & 2 & 2 & - & 2 & - & Confirmed \\
\hline Chorion epithelioma & 1 & 1 & - & 1 & - & Confirmed \\
\hline Chorion epithelioma & 1 & 1 & - & - & 1 & Confirmed \\
\hline Malignant tumours of testicle & 1 & - & 1 & - & 1 & $\begin{array}{l}\text { Confirmed chorion epithelioma, no } \\
\text { spread yet }\end{array}$ \\
\hline Malignant tumours of testicle & 1 & - & 1 & 1 & - & $\begin{array}{l}\text { Confirmed chorion epithelioma, died } \\
\text { multiple metastases }\end{array}$ \\
\hline Malignant tumours of testicle & 4 & - & 4 & - & 4 & Chorion epithelioma not confirmed \\
\hline Total & 59 & 8 & 51 & 8 & 51 & \\
\hline
\end{tabular}

+ Prep
Prepuerin Test Follow-up

correlation with the Prepuerin test. In this test it is also possible to read the results in a few hours. The Ortho Latex test (Ortho Pharmaceutical Ltd.) is based on the property that pregnant urine has of neutralizing anti-human chorionic gonadotrophin antibodies, but in this case the test system in the final stage consists of latex particles coated with human chorionic gonadotrophin (Robbins, Hill, Carle, Carlquist, and Marcus, 1962). These, in the case of pregnancy, should not agglutinate following incubation and centrifugation. We have carried out a number of tests with this material and have found it satisfactory, provided that the centrifuge speed is carefully adjusted. This speed is critical and must be adhered to or false results are obtained. Due also to a personal idiosyncrasy we have found it difficult to read the test but colleagues in this laboratory have not had this experience.

\section{THIN-LAYER CHROMATOGRAPHY TEST}

This is not a haemagglutination inhibition test but depends on the presence of pregnandiol in the urine. Dr. G. Owen, a colleague, has carried out 60 of these

tests in parallel with ours and there is again close correlation. The apparatus, however, is expensive ${ }^{\supset}$ and the technique is, in our view, too specialized for $_{z}^{-}$ this method to be generally adopted. It has, however, proved a useful court of appeal in doubtful cases of abnormal implantation and abortion.

We would like to express our thanks to Dr. A. J.ळ Fulthorpe, of the Wellcome Research Laboratories, for ${ }^{\omega}$ his kindness in making supplies of Prepuerin available. Our thanks are also due to Dr. G. Owen, City Generals Hospital, Sheffield, for help and advice, and to Mr. H. Richards and Mrs. J. Bates for technical assistance.

\section{REFERENCES}

Boyden, S. V. (1951). J. exp. Med., 93, 107.

Fulthorpe, A. J. (1962). Personal communication.

Hobson, B. M. (1953-54). Trans. Edinb. obstet. Soc., 106th session, p. 33. In (1954). Edinb. med., J., 61.

Larkin, I. M. (1955). J. Obstet. Gynaec. Brit. Emp., LXII, 62, 67.

'Peterborough' (1954). London Daily Telegraph, August 19.

Robbins, J. L., Hill, G. A., Carle, B. N., Carlquist, J. H., and Marcus, S. (1962). Proc. Soc. exp. Biol. (N.Y.), 109, 321.

Schwabacher, H., and Elkan, E. (1953). S. Afr. J. med. Sci., 18, 13.

Wide, L., and Gemzell, C. A. (1960). Acta endocr. (Kbh.), 35, 261 